\title{
Pengaruh dosis kascing dan bioaktivator terhadap pertumbuhan dan hasil tanaman sawi (Brassica juncea L.) yang dibudidayakan secara organik
}

\section{The effect of vermi manure dosage and bioactivator on growth and yield of brown mustard (Brassica juncea L.) on organic farming}

\author{
Diterima : 15 Juni 2019/Disetujui : 1 Agustus 2019 / Dipublikasikan : 7 Agustus 2019 \\ CDepartment of Crop Science, Padjadjaran University
}

\begin{abstract}
Brown mustard yield can be increased based on organic farming. The purpose of this study was to determine the effect of vermine compost dose and bioactivactor application on the growth and yield of brown mustard. The experimental design used Randomized Block Design. There were nine treatments: without vermi manure and without bioactivator; vermi manure 5 ton/ha and without bioactivator; vermi manure 5 ton/ha and bioactivator 4 $\mathrm{mL} / \mathrm{L}$; vermi manure 10 ton/ha and without bioactivator; vermi manure 10 ton/ha and bioactivator $4 \mathrm{~mL} / \mathrm{L}$; vermi manure 15 ton/ha and without bioactivator; vermi manure 15 ton/ha and bioactivator $4 \mathrm{~mL} / \mathrm{L}$; vermi manure 20 ton/ha and without biactivator; and vermi manure 20 ton/ha and bioactivator $4 \mathrm{~mL} / \mathrm{L}$; with four replications. The results of experiment showed that all dosages of vermi manure fertilizer and bioactivator increased the plant height, number of leaves, and biomass of plant. Dosage 5 ton/ha vermi manure without biactivator gave the best result on biomass of plant.
\end{abstract}

Keywords : Vermi manure • Bioactivator • Mustard green · Organic farming

Sari. Peningkatan produktivitas sawi (Brassica juncea L.) dapat dilakukan secara organik. Tujuan penelitian ini untuk mengetahui pengaruh dosis kascing dan penggunaan bioaktivator terhadap pertumbuhan dan hasil tanaman sawi. Rancangan yang digunakan adalah Rancangan Acak Kelompok (RAK),

\footnotetext{
Dikomunikasikan oleh Syariful Mubarok

Wahyudin, A. · A. W. Irwan

Staf Pengajar Program Studi Agroteknologi Fakultas

Pertanian Universitas Padjadjaran

Korespondensi: agus.wahyudin@unpad.ac.id
}

terdiri atas sembilan kombinasi perlakuan dan diulang empat kali, masing-masing kombinasi perlakuan adalah: tanpa kascing dan tanpa bioaktivator; kascing 5 ton/ha dan tanpa bioaktivator; kascing 5 ton/ha dan bioaktivator $4 \mathrm{~mL} / \mathrm{L}$; kascing 10 ton/ha dan tanpa bioaktivator; kascing 10 ton/ha dan bioaktivator $4 \mathrm{~mL} / \mathrm{L}$; kascing 15 ton/ha dan tanpa bioaktivator; kascing 15 ton/ha dan bioaktivator $4 \mathrm{~mL} / \mathrm{L}$; kascing 20 ton/ha dan tanpa bioaktivator; serta kascing 20 ton/ha dan bioaktivator $4 \mathrm{~mL} / \mathrm{L}$. Hasil penelitian menunjukkan bahwa pemberian pupuk kascing dan bioaktivator memberikan pengaruh yang nyata terhadap tinggi tanaman, jumlah daun, berat basah tanaman, dan berat kering tanaman dibandingkan dengan tanpa pemberian kascing dan bioaktivator. Dosis pupuk kascing 5 ton/ha tanpa bioaktivator merupakan dosis yang dianjurkan karena memberikan tinggi tanaman, jumlah daun, berat basah, dan berat kering yang sama dibandingkan dengan perlakuan lainnya yang diberi pupuk kascing dan bioaktivator pada dosis yang lebih tinggi.

Kata kunci : Pupuk kascing • Bioaktivator • Tanaman sawi $\cdot$ Budidaya organik

\section{Pendahuluan}

Sayuran merupakan komoditi yang berprospek cerah karena dibutuhkan sehari-hari dan permintaannya cenderung terus meningkat. Sebagaimana jenis tanaman hortikultura lainnya, kebanyakan tanaman sayuran mempunyai nilai komersial yang cukup tinggi. Kenyataan ini dapat dipahami sebab sayuran senantiasa dikonsumsi setiap saat. Sawi 
(Brassica juncea L.) merupakan jenis sayur yang digemari oleh masyarakat Indonesia. Konsumennya mulai dari golongan masyarakat kelas bawah hingga golongan masyarakat kelas atas. Di Indonesia sendiri banyak sekali jenis masakan atau penganan yang menggunakan daun sawi, baik sebagai bahan pokok maupun sebagai bahan pelengkapnya. Hal tersebut menunjukkan bahwa dari aspek sosial, masyarakat sudah menerima kehadiran sawi untuk konsumsi sehari-hari.

Beberapa faktor harus diperhatikan dalam teknik budidaya tanaman sayuran yang secara langsung mempengaruhi pertumbuhannya. Peningkatan kesuburan tanah dan hasil tanaman dapat dilakukan dengan pemberian pupuk organik dan bioaktivator. Pupuk organik yang biasa digunakan untuk budidaya tanaman sayuran adalah pupuk kandang, pupuk hijau, kompos, bokashi, dan kascing. Kascing adalah kotoran cacing tanah yang bercampur dengan tanah atau bahan lainnya yang merupakan pupuk yang sangat baik, di mana zat-zat yang dikandungnya dapat tersedia bagi tanaman. Kascing kaya akan unsur hara dan kualitasnya lebih baik daripada pupuk organik jenis lainnya (Wahyudin, 2016).

Gaddie dan Douglas (1977) menyatakan, kascing mengandung 0,5-2,0 \% $\mathrm{N} ; 0,06-0,68$ $\% \mathrm{P}_{2} \mathrm{O}_{5} ; 0,10-0,68 \% \mathrm{~K}_{2} \mathrm{O}$; dan 0,50-3,50\% Ca. Selain kandungan unsur haranya cukup tinggi, kascing sangat baik untuk pertumbuhan tanaman karena mengandung auksin (Catalan, 1981). Kascing juga mengandung hormon lain, asam humat, enzim-enzim, dan mikroba tanah yang bermanfaat bagi kesuburan tanah. Rahardja (1998) mengemukakan bahwa pada tanah hutan terbakar menunjukkan bahwa kascing dapat meningkatkan jumlah mikroorganisme yang lebih tinggi dibandingkan dengan pemberian pupuk kandang dan kompos (Tabel 1). Hasil penelitian Damayanti (1993, dalam Radian, 1994) pada tanah ultisol dengan tanaman kedelai menunjukkan bahwa kascing dapat menaikkan serapan hara N, P, K dan hasil kedelai hingga $80 \%$, serta meningkatkan kandungan hara dan $\mathrm{pH}$ tanah.

Dewasa ini perhatian pada sistem pertanian akrab lingkungan terus meningkat, hal ini dapat dipahami karena sistem pertanian yang hanya bertumpu pada pemakaian pupuk kimia dan pestisida kimia untuk meningkatkan produktivitas tanaman dapat memberikan dampak negatif terhadap lingkungan
(Djakamihardja, 2010). Upaya untuk meningkatkan hasil dan kualitas sayuran tanpa memberikan pengaruh negatif terhadap lingkungan diantaranya dengan menggunakan bioaktivator. Salah satu bioaktivator yang mulai diterapkan penggunaannya adalah yang bahan dasarnya berasal dari urin ternak dan mikroorganisme tanah.

Diantara faktor-faktor yang menentukan produksi tanaman sayuran adalah pemberian pupuk dasar berupa pupuk organik dan perbaikan lingkungan tumbuh. Pupuk dasar dan perbaikan lingkungan tumbuh sangat berguna untuk menyiapkan tanah pada kondisi sebaik mungkin sehingga dapat memantapkan pertumbuhan tanaman, sebagaimana kondisi tanah yang diinginkan oleh tanaman sawi, yaitu tanah yang gembur, banyak mengandung humus dan subur baik secara fisik, kimia, maupun biologi. Kondisi tanah yang dikehendaki oleh tanaman sawi tersebut dapat diatasi dengan pemberian kascing dan penggunaan bioaktivator.

Berdasarkan informasi - informasi tersebut, jelas bahwa pemberian kascing dan penggunaan bioaktivator dapat meningkatkan kesuburan tanah dan hasil pada berbagai tanaman, aman bagi lingkungan, dan sehat dikonsumsi manusia. Sejauh ini informasi mengenai pengaruh dosis kascing dan penggunaan bioaktivator terhadap perubahan kesuburan tanah dan hasil tanaman sawi belum diketahui dengan jelas, maka perlu dilakukan penelitian ini.

\section{Bahan dan Metode}

Penelitian dilakukan di Rumah Kaca Fakultas Pertanian Unpad Jatinangor dengan jenis tanah Inceptisol pada ketinggian tempat 750 meter di atas permukaan laut. Adapun bahan yang digunakan dalam penelitian ini adalah: benih sawi, kascing, bioaktivator Ston-F, air, tanah latosol Jatinangor, dan polybag. Alat yang digunakan dalam penelitian ini adalah: alat alat pertanian konvensional, ember, peralatan laboratorium, $\mathrm{pH}$ meter, moisture tester, label untuk identitas perlakuan, alat ukur berupa meteran atau mistar, timbangan elektrik, dan alat tulis.

Metode penelitian yang digunakan adalah Rancangan Acak Kelompok (RAK). Adapun perlakuan yang digunakan adalah sebagai berikut: tanpa kascing dan tanpa bioaktivator 
(A); kascing 5 ton/ha dan tanpa bioaktivator (B); kascing 5 ton/ha dengan bioaktivator $4 \mathrm{~mL} / \mathrm{L}$ (C); kascing 10 ton/ha dan tanpa bioaktivator (D); kascing 10 ton/ha dengan bioaktivator $4 \mathrm{~mL} / \mathrm{L}$ (E); kascing 15 ton/ha dan tanpa bioaktivator (F); kascing 15 ton/ha dengan bioaktivator $4 \mathrm{~mL} / \mathrm{L}(\mathrm{G})$; kascing 20 ton/ha dan tanpa bioaktivator $(\mathrm{H})$; serta kascing 20 ton/ha dan bioaktivator $4 \mathrm{~mL} / \mathrm{L}$ (I). Semua perlakuan diulang empat kali, sehingga terdapat 36 pot percobaan. Pengamatan dilakukan terhadap tinggi tanaman, jumlah daun, berat basah tanaman, dan berat kering tanaman.

\section{Hasil dan Pembahasan}

Tinggi Tanaman dan Jumlah Daun. Data dan hasil analisis statistik tinggi tanaman dan jumlah daun setelah percobaan tertera pada Tabel 1 .

Tabel 1. Pengaruh dosis kascing dan bioaktivator terhadap tinggi tanaman dan jumlah daun pada akhir percobaan (35 hari setelah tanam).

\begin{tabular}{|c|c|c|}
\hline Perlakuan & $\begin{array}{l}\text { Tinggi tanaman } \\
(\mathrm{cm})\end{array}$ & Jumlah daun \\
\hline $\mathrm{A}$ & $24,25 \mathrm{a}$ & $6.00 \mathrm{a}$ \\
\hline B & $35,50 \mathrm{~b}$ & $7.75 \mathrm{~b}$ \\
\hline C & $35,75 \mathrm{~b}$ & $8.50 \mathrm{~b}$ \\
\hline $\mathrm{D}$ & $37,75 \mathrm{~b}$ & $8.75 \mathrm{~b}$ \\
\hline E & $36,25 \mathrm{~b}$ & $9.25 \mathrm{~b}$ \\
\hline $\mathrm{F}$ & $38,50 \mathrm{~b}$ & $8.75 \mathrm{~b}$ \\
\hline G & $36,75 \mathrm{~b}$ & $9.00 \mathrm{~b}$ \\
\hline $\mathrm{H}$ & $36,75 b$ & $8.00 \mathrm{~b}$ \\
\hline I & $38,25 \mathrm{~b}$ & $9.00 \mathrm{~b}$ \\
\hline
\end{tabular}

Keterangan : Nilai rata-rata yang diikuti oleh huruf yang sama arah vertikal, tidak berbeda nyata menurut Uji Jarak Berganda Duncan pada taraf 5\%.

Hasil analisis yang tercantum pada Tabel 1 menunjukkan bahwa pemberian kascing dan bioaktivator mampu meningkatkan tinggi tanaman dan jumlah daun secara nyata dibandingkan dengan tanpa pemberian kascing dan bioaktivator, tetapi di antara perlakuan pemberian kascing dan bioaktivator itu sendiri tidak berbeda nyata. Penambahan pupuk kascing dapat meningkatkan kandungan humus di dalam tanah. Humus merupakan koloid tanah dan merupakan bahan aktif karena mempunyai ukuran fraksi sama atau lebih kecil dari fraksi liat. Dengan ukuran fraksi yang kecil berarti mempunyai luas permukaan yang besar, sehingga koloid pupuk kascing mampu menyerap atau menyangga ion-ion hara, terutama unsur hara nitrogen yang merupakan unsur yang paling mudah hilang dari dalam tanah, karena selain bersifat higroskopis juga mudah larut tercuci oleh aliran air (Nurmala et. al., 2017).

Penambahan pupuk organik dapat memperbaiki sifat fisik, biologi, meningkatkan kapasitas kemampuan tanah dalam menyediakan unsur hara, dan menyediakan unsur hara penting bagi tanaman secara berkelanjutan melalui mineralisasi pupuk organik (Meena et. al., 2015). Kandungan nitrogen di dalam tanah dapat meningkat setelah diberi pupuk kascing dan bioaktivator. Hal ini dapat disebabkan oleh beberapa faktor. Pupuk kascing dapat menyumbangkan unsur nitrogen meskipun jumlahnya kecil. Meningkatnya unsur nitrogen di dalam tanah juga disebabkan oleh adanya bakteri amonifikasi, Rhizobium, dan Azotobacter yang dikandung dalam bioaktivator Ston-F dan kascing, sehingga laju mineralisasi dan pengikatan senyawa nitrogen bebas meningkat. Pemberian pupuk kascing menyebabkan kandungan nitrogen di dalam tanah meningkat sehingga serapan nitrogen oleh tanaman pun meningkat pula. Peningkatan serapan nitrogen menyebabkan kandungan klorofil tanaman menjadi lebih tinggi sehingga laju fotosintesis meningkat. Laju fotosintesis meningkat menyebabkan sintesis karbohidrat juga meningkat. Pembentukan karbohidrat yang disebabkan oleh laju fotosintesis akan meningkatkan pertumbuhan vegetatif tanaman termasuk pertumbuhan tinggi tanaman dan pembentukan daun.

Berat Basah dan Berat Kering Tanaman. Data dan hasil analisis statistik berat basah dan berat kering tanaman setelah percobaan tertera pada tabel 2 .

Tabel 2. Pengaruh dosis kascing dan bioaktivator terhadap berat basah dan berat kering tanaman pada akhir percobaan ( 35 hari setelah tanam).

\begin{tabular}{cll}
\hline Perlakuan & Berat Basah $(\mathrm{g})$ & Berat Kering $(\mathrm{g})$ \\
\hline A & $15.085 \mathrm{a}$ & $0.932 \mathrm{a}$ \\
$\mathrm{B}$ & $76.727 \mathrm{~b}$ & $4.474 \mathrm{~b}$ \\
C & $75.692 \mathrm{~b}$ & $4.294 \mathrm{~b}$ \\
$\mathrm{D}$ & $87.156 \mathrm{~b}$ & $5.305 \mathrm{~b}$ \\
E & $68.329 \mathrm{~b}$ & $4.128 \mathrm{~b}$ \\
F & $86.648 \mathrm{~b}$ & $5.000 \mathrm{~b}$ \\
G & $84.194 \mathrm{~b}$ & $4.730 \mathrm{~b}$ \\
H & $92.137 \mathrm{~b}$ & $5.163 \mathrm{~b}$ \\
I & $104.544 \mathrm{~b}$ & $6.331 \mathrm{~b}$ \\
\hline
\end{tabular}

Keterangan : Nilai rata-rata yang diikuti oleh huruf yang sama arah vertikal, tidak berbeda nyata menurut Uji Jarak Berganda Duncan pada taraf 5\%. 
Hasil analisis yang tercantum pada Tabel 2 menunjukkan bahwa pemberian pupuk kascing dan bioaktivator mampu meningkatkan berat basah dan berat kering tanaman secara nyata dibandingkan dengan tanpa pemberian kascing dan bioaktivator, tetapi di antara perlakuan pemberian kascing dan bioaktivator itu sendiri tidak berbeda nyata. Penambahan bahan organik kedalam tanah dapat memperbaiki struktur tanah, meningkatkan aktivitas mikroba tanah, meningkatkan daya tahan terhadap air, meningkatkan kapasitas tukar kation dan meningkatkan kandungan unsur hara diantaranya nitrogen (Yuliana $d k k ., 2015$ ). Peningkatan berat basah dan berat kering tanaman pada perlakuan pemberian pupuk kascing dan bioaktivator berkaitan erat dengan peningkatan serapan nitrogen. Serapan nitrogen yang meningkat menyebabkan kebutuhan nitrogen pada fase vegetatif tanaman tercukupi, sehingga meningkatkan biomassa tanaman.

Menurut Russel (1977), nitrogen merupakan suatu unsur yang paling banyak dibutuhkan dalam hubungannya dengan pertumbuhan tanaman. Unsur ini dijumpai dalam jumlah besar pada bagian jaringan tanaman yang muda daripada dijaringan tanaman yang tua, terutama berakumulasi pada bagian daun dan biji. Nitrogen merupakan unsur penyusun setiap sel hidup, karenanya terdapat pada seluruh bagian tanaman dan dibutuhkan sepanjang pertumbuhannya. Dengan demikian jumlah nitrogen yang diserap tanaman dari dalam tanah berhubungan langsung dengan berat basah dan berat kering tanaman.

\section{Kesimpulan}

Pemberian pupuk kascing dan bioaktivator memberikan pengaruh yang nyata terhadap tinggi tanaman, jumlah daun, berat basah tanaman, dan berat kering tanaman dibandingkan dengan tanpa pemberian kascing dan bioaktivator, tetapi di antara perlakuan kascing dan bioaktivator itu sendiri tidak berbeda nyata. Dosis pupuk kascing 5 ton/ha tanpa bioaktivator merupakan dosis yang dianjurkan karena memberikan tinggi tanaman, jumlah daun, berat basah, dan berat kering yang sama dibandingkan dengan perlakuan lainnya yang diberi pupuk kascing dan bioaktivator.

\section{Daftar Pustaka}

Agus Wahyudin. 2016. Bahan Ajar Dasar Teknologi Produksi Tanaman. Program Studi Agroteknologi. Fakultas Pertanian Unpad. Bandung.

Andi Riswandi R. 1998. Pengaruh Pemberian Beberapa Bahan Organik Terhadap Total Bakteri Tanah dan Hasil Tanaman Kedelai (Glycine max L.) Pada Tanah Hutan Terbakar. Skripsi.Fakultas Pertanian UNPAD. Jatinangor.

Catalan, I.G. 1981. Eartworm A New Source Protein. The Phillipine Earthworm Center.Manila.

Djakamihardja, S. 2010. Pertanian Organik Sebagai salah Satu Teknologi Pertanian Alternatif. Bahan Seminar di Jurusan Budidaya Pertanian Fakultas Pertanian Unpad. Jatinangor

Gaddie, R.E and B.E. Douglas. 1977. Earthworm for Ecolofy and Profit. Vol. II. Published by Bookworm Publishing Company, P.O. Box 3037. Ontario.California 91761. Printed in The United State.

Meena, R.S., Dhakal, J.S. Bhora, S.P. Singh, M.K. P. Sanodiya, and H. Meena. 2015. Influence of Bioinorganic Combination on Yield, Quality and Economics of Mung Bean. Am. J. Of Exp. Agric. Vol. 8(3): 159-166.

Radian. 1994. Cara pembuatan Kascing dan Peranannya dalam Meningkatkan Produktivitas Tanah. Paper.Program Pasca Sarjana Universitas Padjadjaran. Bandung.

Russel, R.S. 1977. Plant Root System : Their Function and Interation With Soil. Mc. Graw Hill Book Company Limited. London.

Tati Nurmala, Aep W.I., Agus W., Fiky Y.W. 2017. Agronomi Tropis. Pustaka Giratuna. Bandung.

Yuliana, E. Rahmadani, Permanasari. 2015. Aplikasi Pupuk Kandang Ayam Terhadap Pertumbuhan dan Hasil Tanaman Jahe ( Zingiber officinale Rosc.) di Media Gambut. Jurnal Agroteknologi. Vol. 4, No 2 : 37-42. 